\title{
Blood Profile of Implantation Stainless Steel 316L Local Implant Material on Rat Femoral Bone
}

\author{
Gustian ${ }^{1}$, Soehartono $\mathrm{H}^{1}$, Jujur $\mathrm{N}^{2}$, Wargadipura $\mathrm{AHS}^{2}$, Noviana $\mathrm{D}^{1}$ \\ ${ }^{1}$ Faculty of Veterinary Medicine, Bogor Agricultural University \\ ${ }^{2}$ Center for Technology Services, Agency for the Assessment and Application of Technology \\ E-mail: tian_borneo@yahoo.co.id
}

(received 26-06-2018; revised 08-08-2018; accepted 13-08-2018)

\begin{abstract}
ABSTRAK
Gustian, Soehartono H, Jujur N, Wargadipura AHS, Noviana D. 2018. Profil darah implantasi stainless steel 316L bahan implan lokal pada tulang femoralis tikus. JITV 23(3): 123-129. DOI: http://dx.doi.org/10.14334/jitv.v23i3.1836

Penelitian ini bertujuan untuk mengetahui profil darah tikus putih pasca-implantasi stainless steel 316L produk lokal asli Indonesia sebagai material implan metal tahan karat tidak terserap tubuh. Tiga puluh ekor ekor tikus strain sprague dawley (SD) jantan, dewasa, berusia 12 minggu dibagi ke dalam 3 kelompok yaitu kelompok kontrol tanpa implantasi, kelompok implan stainless steel 316L impor dan kelompok implan stainless steel 316L lokal yang dikembangkan Badan Pengkajian dan Penerapan Teknologi (BPPT). Pada kelompok perlakuan, material implan disisipkan diantara os femur dengan otot biceps femoris. Pada kelompok kontrol, os femur hanya dibuat defek tanpa dimasukkan material implan. Pemeriksaan respon sistemik dilakukan dengan pemeriksaan darah lengkap sebelum dan 30 hari sesudah implantasi. Hasil analisis pemeriksaan jumlah sel darah merah, kadar hemoglobin, nilai hematokrit, mean corpuscular volume (MCV), mean corpuscular hemoglobin (MCH), mean corpuscular hemoglobin concentration (MCHC), jumlah sel darah putih total dan diferensiasi sel darah putih antar kelompok perlakuan tidak menunjukkan perbedaan yang nyata. Sebagai kesimpulan, material implan stainless steel 316L impor maupun produk lokal tidak memberikan respon negatif terhadap profil darah hewan.
\end{abstract}

Kata Kunci: Stainless Steel, Implan Metal, Biokompatibilitas, Profil Darah, Reaksi Benda Asing

\section{ABSTRACT}

Gustian, Soehartono H, Jujur N, Wargadipura AHS, Noviana D. 2018. Blood profile of implantation stainless steel 316L local implant material on rat femoral bone. JITV 23(3): 123-129. DOI: http://dx.doi.org/10.14334/jitv.v23i3.1836

This study was aimed to obtain information regarding complete blood count (CBC) profile of post implantation of stainless steel (SS) 316L as an Indonesian local product of non-degradable metal implant. Thirty adult male rat, aged approximately 12 weeks were divided into 3 groups, i.e. control group without implantation, implant group with import SS316L and implant group with Indonesian national local SS316L that developed by Agency for the Assessment and Application of Technology (BPPT). The implant groups were given implants by inserting it between femoral bone and biceps femoris muscle. On the control group, defect was made on bone without inserting an implants material. Examination of the systemic response was done with CBC before and 30 days after implantation. The analysis of red blood cells amount, haemoglobin level, haematocrite value, mean corpuscular volume (MCV), mean corpuscular hemoglobin (MCH), mean corpuscular hemoglobin concentration (MCHC), total white blood cell and its differentiation from each group did not show significant differences. In conclusion, stainless steel 316L of import and national local product showed non-negative effects on blood profile.

Key Words: Stainless Steel, Metal Implant, Biocompatibility, Blood Profile, Foreign Body Reaction

\section{INTRODUCTION}

Nowadays, the technological advances in the field of materials for orthopaedic implantation have been highly developed (Nielsen et al. 2018). Bone is a major part of the body support, motion devices, body frame shaper and mineral storage (Kennedy et al. 2018). Various activities can be harmful to bones such as internal factors like age and external factors such as sports or even accidents (Lely et al. 2012). The bone damage can reduce its strength, thereby decreasing the mechanical functions of the body (McClung et al.
2018). Based on the results of research by the Research and Development Board of the Health Department Republic Indonesia in 2013, the number of injury incidents in Indonesia increased significantly from the year 2007. Common fracture cases occur in Indonesia caused by injuries such as falls, traffic accidents and sharp or blunt trauma (Kemenkes RI 2013). One way to deal with damage to bones and joints is to place biomaterials in the affected part (Krecisz et al. 2006).

Handling of fractures using metal pins such as stainless steel and titanium are mostly imported products (BPS 2012; Lely et al. 2012). Among the most 
common medical devices in Indonesia are imported products, while local health equipment products also require imported raw materials (PTM-BPPT 2017). Metallic biomaterials are often used to replace framework components of the human body such as artificial joints, bone plates, backbone attachments and tooth grafts (Bombac et al. 2007; Hafizi et al. 2016). The metallic biomaterial that is often used as an orthopaedic implant material is 316L stainless steel (SS316L) (Hafizi et al. 2016). Some studies consider that stainless steel has a corrosion resistance (Hermawan et al. 2011; Perren et al. 2017).

Some studies about local stainless steel casting manufacturers that use induction furnaces are highly dependent on imported raw materials (Jujur et al. 2015) The increasing demand of the SS316L orthopaedic material every year drives Indonesia to have a cheaper local substitute which availability can always be ensured (BPS 2012). The improvement of the infrastructure and an enormous amounts of natural resources as raw materials in Indonesia, reinforced the development of 316L stainless steel local products (Jujur et al. 2015). Stainless steel is an alloy of steel, iron, nickel and chromium containing the form a protective layer of oxidation, therefore this material is practically immune to rusting and corrosion (Lely et al. 2012; Manivasagam et al. 2010).

The Agency for the Assessment and Application of Technology (BPPT) together with local industry is developing the production of stainless steel implant components based on local resources for the medical equipment industry. The development is done to increase the added value of local resources in order to substitute the import of raw materials, health equipment products and to improve the independence of the nation. The components composition of stainless steel 316L local implant material are based on the import stainless steel 316L, in accordance with American Society for Testing and Materials (ASTM) number F-138. This material is the first material based from local raw and made in Indonesia (with government program) (Jujur et al. 2015). The local stainless-steel products are required to take a series of biocompatibility tests, in order to be used and legally distributed on the market in accordance with medical equipment standard (Hamidi et al. 2017). Blood tests as one of the biocompatibility tests will indicate a particular physiological condition of the individual (Keohane et al. 2015), therefore blood can be one of the main parameters in preclinical / biomedical research. This research needs to be done to find out animal blood profile on implantation of 316L stainless steel biomaterials of the local product as one of biocompatibility test (Krecisz et al. 2006; Larsson et al. 2007). It will indicate the body's systemic response to acceptance or rejection of implanted material (Fitria \& Sarto 2014).

\section{MATERIALS AND METHODS}

\section{Period and study place}

This research was conducted at the Veterinary Teaching Hospital Faculty of Veterinary Medicine of Bogor Agricultural University. This research was approved by Animal Ethics Committee Institute of Bogor Agricultural University with certificate number 79-2017 IPB.

\section{Research material}

Sprague Dawley rats aged 16 weeks with a range of 250-300 g weight were used in this study. 30 experimental rats derived from Indonesian Food and Drug Supervisory Agency were divided into three treatment groups: group without implantation as a negative control, 316L stainless steel implantation imported group as well as $316 \mathrm{~L}$ stainless steel implantation local group which resulted from the cooperation and development of Agency for Assessment and Application of Technology. Ten rats in each group were divided randomly.

The equipment used were blood sample, mouse cage, syringe, rat restraint device, operating table, shaver, one unit of minor operation equipment including surgical shears, tissue forceps, haemostatic clamp, clamp towel, sterile tampon, scalpel, blade, needle holder, cotton, gauze, razor, needle and sewing threads absorbed by body polyglactin, dental drill, syringe, vacuum tube containing anticoagulant Ethylenediamine Tetraacetic Acid (EDTA) as blood samples container and blood test equipment.

The chemical composition requirements for stainless steel bone implants were specified in the ASTM F 138 (Laing 1979) and ISO 5832-1 specifications. The limits of the chemical composition for bone implants in both the ASTM and ISO standards were nearly identical. The limit were $0.03 \%$ Carbon, $0.75 \%$ siclicon, $2.00 \%$ for mangan, 0.025 for phosphate, $0.01 \%$ for sulphur, $17-19 \%$ chromium, $13-$ 15\% nickel, 2.25-3.0\% molibdenum, $0.1 \%$ nitrogen, 0.5 cuprum and balance ferrum. The local stainless steel made by BPPT is based from that decision. The result of scanning electron microscope (SEM) that was equipped with EDS from this medical grade stainless steel 316L national local product were $0.028 \%$ Carbon, $0.610 \%$ siclicon, $1.20 \%$ for mangan, 0.025 for phosphate, $0.0039 \%$ for sulphur, $18.86 \%$ chromium, 10.89\% nickel, $2.13 \%$ molibdenum, and balance ferrum (Jujur et al. 2015). 


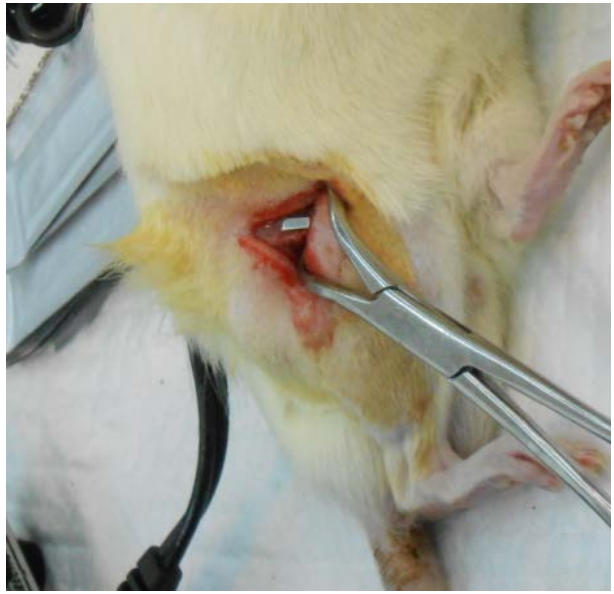

(A)

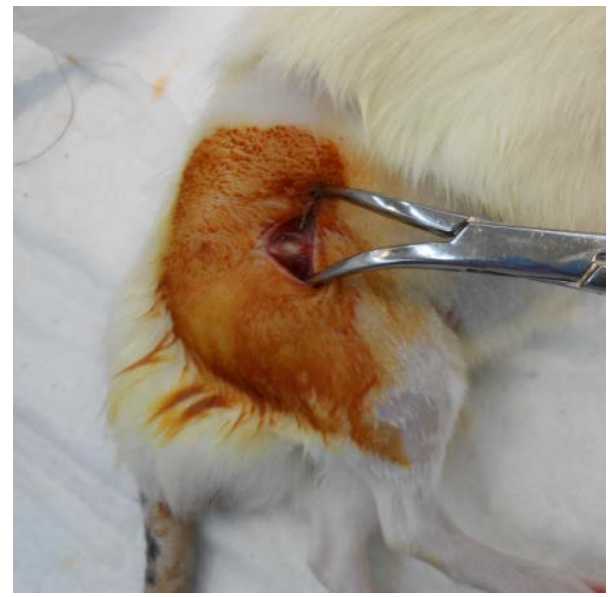

(B)

Figure 1. Implantation area without material (A), material implanted on os femur defect (B).

\section{Implantation of material}

The 316L stainless steel implantable biomaterial of a local product developed by the Materials Technology Center of the Agency for Assessment and Application of Technology (PTM-BPPT) is $5 \times 2 \times 1 \mathrm{~mm}$ in size. The implantation in rats was performed by aseptic surgery. Prior to surgery, the surgical device was sterilized at an oven with a temperature of $121^{\circ} \mathrm{C}$ for 1 hour and the equipment carrier was sterilized at $75^{\circ} \mathrm{C}$ for 1 hour. The process of surgery begins with the preparation of animals and the preparation of operators in accordance with the procedure. All surgical procedures were under the influence of the Ketamine-Xylazine anaesthetic agent. Anaesthesia was performed intraperitoneally with a dose of $40 \mathrm{mg} / \mathrm{kgBW}$ and $5 \mathrm{mg} / \mathrm{kgBW}$, respectively. After the anaesthesia process was completed and the animal in anaesthetic condition, hair was shaved in the lateral area of the right leg femoral rear and disinfected using 70\% alcohol and 10\% povidone-iodine.

Figure 1 shows the surgery performed on the lateral of the right leg os femur of the experimental animal. Skin and musculus biceps femoris is slashed along muscle fibre and parallel to the bone position so that the injured area does not dilate and facilitate the placement of implantable material. Muscles were exposed to the appearance of the os femur after the skin and muscles are slashed. The diafisis of os femur area was then scraped using dental drill to make bone defects. The erosion should be done carefully so that the penetration of the drill was not too deep and in accordance with the expected size. The part of the scraped bone is adjusted to the size of the implant material that is $5 \times 2 \times 1 \mathrm{~mm}$. The implantable material was planted in accordance with its position and fixed to remain in the same place.
On the control group, defect was made on bone without inserting an implants material, but the treatment was same with other groups. Closing the network was done by sewing a simple method using a special sewing thread. Post-operative treatment was administered with antibiotic amoxicillin and clavulanic acid orally at a dose of $15 \mathrm{mg} / \mathrm{kg}$ body weight 2 times daily for 7 days. After the implantation process is completed then done the observation periodically according to the test conducted.

\section{Blood sampling}

Blood sampling was performed in all aseptic treatment groups performed on day 7 prior to implantation and the 30th day after implantation. Blood sampling was done through animal tail using $3 \mathrm{ml}$ syringe.

Firstly, rats were anesthetized by a combination of ketamine and xylazine anaesthesia with doses of 40 $\mathrm{mg} / \mathrm{kgBW}$ and $5 \mathrm{mg} / \mathrm{kgBW}$, respectively. The tail area is disinfected with alcohol and a blood sample was taken at least $1 \mathrm{ml}$ inserted into a purple vacuum tube containing EDTA for haematological examination. Blood sample collected was temporarily stored in the cooling box until a laboratory examination.

The examination was done on complete blood count including the amounts of erythrocytes, leucocytes, platelets, haemoglobin, haematocrit, Mean Corpuscular Volume/MCV (Mean volume of one erythrocyte grain), Mean Corpuscular Haemoglobin/MCH (mean weight haemoglobin in one erythrocyte), Mean Corpuscular Haemoglobin Concentration (MCHC) (mean haemoglobin concentration in one erythrocyte) and differential leucocytes such as basophils, eosinophils, neutrophils, lymphocytes and monocytes. The direct 
blood image will show the systemic animal condition of the body's response to orthopaedic biomaterials implant.

\section{Experiment design and data analysis}

The experimental rats were divided into three treatments in a complete randomized design. Data were analysed using ANOVA. If treatment is significant, then the difference in mean value is tested by Duncan test (Steel \& Torrie 1995).

\section{RESULTS AND DISCUSSION}

Red Blood Cell (RBC), hemoglobin, platelets, hematocrit, MCV, MCH, and MCHC

The description of the red blood cells, haemoglobin, thrombocytes, haematocrit, MCV, MCH and MCHC are presented in Table 1. The RBC shows no significant difference in the SS316L imported implant treatment group, local SS316L and control at day 7 before and day 30 after the implantation.

The haemoglobin $(\mathrm{Hb})$ rate of rats in Table 1 showed no significant difference between the control group, the import implant treatment group and the local implant treatment group on day 7 before implantation and day 30 after the implantation.

The haematocrit values of the control group and the implant treatment group on day 7 before and day 30 after implantation showed no significant difference. The values obtained by examination on these three parameters are still included in the normal range of values according to the control group without implantation.

MCV, MCH and MCHC values before and after implantation in each treatment were not significantly different. MCV, $\mathrm{MCH}$ and MCHC values may indicate anaemia in animals (Sinno \& Prakash 2013), but on the basis of blood tests obtained between implantable control treatments, implantation with imported SS316L and implantation with SS316L local products showed no significant difference. This is in line with the results of erythrocyte examination, which means that the implanted material provided has no effect on the systemic condition of the experimental animals.

\section{Overview of white blood cells and differential leukocytes}

Description of the white blood cell and differential leukocyte is presented in Table 2. The white blood cell in the control group, the SS316L imported implant treatment group and the local SS316L on day 7 before and day 30 after implantation showed no significant difference. The percentage of differential leukocytes such as basophils, eosinophils, banded netrophils, segment netrophils, lymphocytes and monocytes in the SS316L imported implant treatment group, local SS316L and control groups at day 7 before and 30th day after implantation showed no significant difference The percentage of white blood of rat and its differentiation include basophils, eosinophils, stem neutrophils, netrophil segments, lymphocytes and monocytes between controls and both implantation stainless steel 316L imported and local treatment did not decrease or increase significantly from seven days

Table 1. Red blood cell (RBC) profile, haemoglobin, platelets, haematocrit, MCV, MCH, and MCHC rats before and after 316L stainless steel implantation

\begin{tabular}{|c|c|c|c|c|c|c|}
\hline \multirow{2}{*}{$\begin{array}{l}\text { Blood Para- } \\
\text { meters }\end{array}$} & \multicolumn{3}{|c|}{ H-7 Before Implantation } & \multicolumn{3}{|c|}{$\mathrm{H}+30$ After Implantation } \\
\hline & Control & Import SS316L & Local SS316L & Control & Import SS316L & Local SS316L \\
\hline $\mathrm{Hb}$ & $12.28 \pm 0.82$ & $11.91 \pm 0.56$ & $12.28 \pm 0.58$ & $14.30 \pm 0.52$ & $14.16 \pm 1.36$ & $14.00 \pm 0.85$ \\
\hline Platelet & $279.69 \pm 49.56$ & $278.82 \pm 51.52$ & $302.08 \pm 66.22$ & $401.62 \pm 36.83^{b}$ & $353.00 \pm 57.83^{\mathrm{a}}$ & $332.67 \pm 56.63^{\mathrm{a}}$ \\
\hline $\mathrm{Ht}$ & $36.85 \pm 2.41$ & $35.73 \pm 1.85$ & $36.92 \pm 1.73$ & $42.62 \pm 1.45$ & $41.82 \pm 3.75$ & $41.67 \pm 2.35$ \\
\hline Eritrosit & $4.06 \pm 0.26$ & $3.95 \pm 0.19$ & $4.05 \pm 0.21$ & $4.74 \pm 0.17$ & $4.70 \pm 0.45$ & $4.65 \pm 0.29$ \\
\hline MCV & $89.85 \pm 0.38$ & $90.00 \pm 0.00$ & $89.67 \pm 0.49$ & $88.31 \pm 0.63$ & $88.45 \pm 0.69$ & $88.67 \pm 0.65$ \\
\hline $\mathrm{MCH}$ & $30.00 \pm 0.00$ & $30.00 \pm 0.00$ & $30.00 \pm 0.00$ & $30.00 \pm 0.00$ & $30.00 \pm 0.00$ & $30.00 \pm 0.00$ \\
\hline MCHC & $33.15 \pm 0.38$ & $33.00 \pm 0.00$ & $33.33 \pm 0.49$ & $33.15 \pm 0.38$ & $33.36 \pm 0.50$ & $33.25 \pm 0.45$ \\
\hline
\end{tabular}

Description: Different notations on the same line show very significant differences $(\mathrm{P}<0.01)$

$\mathrm{Hb} \quad$ : Hemoglobin

Ht : Hematokrit

MCV : Mean Corpuscular Volume

$\mathrm{MCH} \quad$ : Mean Corpuscular Haemoglobin

MCHC : Mean Corpuscular Haemoglobin Concentration 
Table 2. White blood cell (WBC) and rat leukocyte differential profile before and after 316L stainless steel implantation

\begin{tabular}{lcccccc}
\hline \hline \multirow{2}{*}{ Blood Parameters } & \multicolumn{3}{c}{ H-7 Before Implantation } & \multicolumn{3}{c}{ H+30 After Implantation } \\
\cline { 2 - 7 } & Control & Import SS316L & Local SS316L & Control & Import SS316L & Local SS316L \\
\hline Leukocyte & $8.75 \pm 2.84$ & $8.98 \pm 2.31$ & $8.68 \pm 1.75$ & $9.08 \pm 2.10$ & $9.61 \pm 2.16$ & $7.85 \pm 2.21$ \\
Basophils & 0 & 0 & 0 & 0 & 0 & 0 \\
Eusinophils & $1.38 \pm 052$ & $1.17 \pm 0.41$ & $1.17 \pm 0.41$ & $1.33 \pm 0.58$ & $1.00 \pm 0.00$ & $1.33 \pm 0.58$ \\
N. Banded & $2.45 \pm 0.52$ & $2.00 \pm 0.00$ & $2.22 \pm 0.44$ & $2.00 \pm 0.00$ & $2.00 \pm 0.53$ & $2.00 \pm 0.00$ \\
N.Segment & $63.00 \pm 8.24$ & $64.45 \pm 7.98$ & $65.50 \pm 5.40$ & $70.31 \pm 5.68$ & $70.64 \pm 6.53$ & $69.92 \pm 6.40$ \\
Limphocytes & $30.23 \pm 5.90$ & $29.64 \pm 6.41$ & 28.584 .29 & $25.31 \pm 4.35$ & $24.27 \pm 6.05$ & $25.92 \pm 6.16$ \\
Monocytes & $3.85 \pm 1.63$ & $2.91 \pm 1.38$ & $3.67 \pm 1.67$ & $2.92 \pm 1.44$ & $3.73 \pm 1.27$ & $2.50 \pm 0.80$ \\
\hline
\end{tabular}

Description : Different notations on the same line show very significant differences $(\mathrm{P}<0.01)$

N. Banded : Banded Netrophils

N. Segment : Segmented Netrophils

before and thirty days after implantation. These results suggest that local SS316L and imported SS316L implants have no effect on the white blood cell profile and the systemic white blood cell differential.

\section{Discussion}

Red Blood Cell (RBC), hemoglobin, platelets, hematocrit, MCV, MCH, and MCHC

In this study, rat's body does not have a deficiency of red blood cells when the implantation process is done and it can be assumed that the implantation process works well (Perren et al. 2017). Haemolysis may occur as a result of a foreign material inserted into the body causing rupture of red blood cells, it will also be directly related to the amount of haemoglobin in the body that would indicate the acceptance or rejection of the foreign body in the body (Keohane et al. 2015). In this case, the results obtained between both erythrocytes and haemoglobin were not significantly different between treatments which means that there was no effect on the body on the implantation of the material.

Thrombocyte levels in the control group without implantation increased on the thirtieth day after implantation compared to the treatment group with imported and local SS316L implantation. The main function of thrombocyte is to protect blood vessels against endothelial damage due to trauma as a prelude

o healing wounds in the walls of blood vessels. The implantation procedure in this study through the operation process can cause injury, damage to skin tissue and muscle damage due to slicing, while damage to bone also occurs due to the manufacture of defects. The tissue damage leads to wound healing reactions that begin with acute inflammation and blood clots by platelets (Perren et al. 2017).
In the event of injury, the damaged tissue thrombocyte will release thromboplastin which reacts with the protrombin and calcium to form thrombin. The thrombin will react with fibrinogen to form fibrin which will cover the wounded tissue (Fitria \& Sarto 2014; Sinno \& Prakash 2013). The decline in thrombocyte count in the blood circulation at the onset of the injury will accompany the event. Levels of thrombocyte on negative control after implantation experienced a significantly different increase slammed two other treatment groups, this can be due to the surgical process cut wounds and bone made defects without implantation of the material, resulting in wound tissue more than two other treatments. As early as the process of wound, thrombocyte in the circulation decreases as most of the thrombocyte lead to injured tissue in the surgical area (Anderson et al. 2008). Thirty days after implantation, the body has produced large amounts of thrombocyte to suffer the number of thrombocyte that continue to be sent to the tissues, thereby still finding high thrombocyte counts in the circulation (Sinno \& Prakash 2013). This is also in accordance with Keohane's et al. (2015) statement, the production of thrombocyte by the body will continue to be done as a reciprocal of the decline in the number of thrombocyte in the circulation. The level of thrombocyte in this case was in normal level in accordance to the control group without implantation.

\section{Overview of white blood cells and differential leukocytes}

The first tissue in the body that will always be the entrance for foreign bodies including the implant material was blood, it goes through a series of bodily biological processes followed by various bodily responses (Anderson 2001; Keohane et al. 2015). The implant planting operation process in this study will 
also affect the profile of white blood cells from animals. The body's response processes that generally follow the process were haemolysis, blood clot formation and then inflammatory processes that will involve white blood cells (Perren et al. 2017). Implantation of biomaterials in the animal body was a form of injury, a process of interaction between blood and material, acute and chronic inflammation, granulation tissue formation and fibrous capsule formation or fibrosis (Anderson et al. 2008). Components of white blood cells such as basophils, eosinophils, banded neutrophils, segmented neutrophils, lymphocytes and monocytes are small in normal conditions, but when there are antigens or foreign bodies such as implantable material inserted into the body, the body reacts, resulting in an increase in the blood cell component (Keohane et al. 2015).

White blood cells serve as the body's defense system against infectious agents as well as foreign objects that enter the body (Saputri et al. 2012). White blood cells are formed in the bone marrow and lymphoid tissues which are then circulated to all parts of the body that are in need especially during infectious and inflammatory processes (Keohane et al. 2015).

In this study, the percentage of white blood of rat and its differentiation include basophils, eosinophils, stem neutrophils, netrophil segments, lymphocytes and monocytes between controls and both implantation stainless steel 316L imported and local treatment did not decrease or increase significantly. These results suggest that local SS316L and imported SS316L implants have no effect on the white blood cell profile and the systemic white blood cell differential (Keohane et al. 2015; Saputri et al. 2012).

The results obtained on monocyte calculations was increase that occurred 30 days after implantation, but the figures obtained did not show a real difference. This is in accordance with Anderson (2001) statement, on the inflammatory process due to implantation of foreign matter, the first few days will be dominated by neutrophils which are then replaced by monocytes. The subsequent monocytes differentiate into macrophages (Anderson 2001).

\section{CONCLUSION}

In this researh, we investigated the medical grade 316L stainless steel biocompatibility from blood profile. The result of this study shows that material implant of import and medical grade 316L stainless steel of local product are not different significantly with control (without implantation), stainless steel 316L of import and national local product showed non-negative effects on blood profile.

\section{ACKNOWLEDGMENT}

The authors would like to thank the Ministry of Research and Higher Education and the Center for Materials Technology and the Agency for the Assessment and Application of Technology (BPPT) for support this study.

\section{REFERENCES}

Anderson JM, Rodriguez A, Chang DT. 2008. Foreign body reaction to biomaterials. Sem Immunol. 20:86-100.

Anderson JM. 2001. Biological responses to materials. Ann Rev Mater Res. 31:81-110.

[BPS] Badan Pusat Statistik. 2012. Data ekpor-impor berdasarkan komoditi HS 8458-8463 tahun 2005-2012. [accessed December 13th 2017]. https://www.bps.go.id/publikasi.html.

Bombac D, Brojan MP, Fajfar F, Kosel, Turk R. 2007. Review of materials in medical aplications. RMZ-Mat Geo Env. 54:471-499.

Fitria L, Sarto M. 2014. Profil hematologi tikus (Rattus norvegicus) galur wistar jantan dan betina umur 4, 6, dan 8 minggu. Biogenesis. 2:94-100.

Hafizi I, Widjijono W, Soesatyo MHN. 2016. Penentuan konsentrasi stainless steel 316L dan kobalt kromium remanium GM-800 pada uji GPMT. Majalah Kedokteran Gigi Indonesia. 2:16-18.

Hamidi MFFA, Harun WSW, Samykano M, Ghani SAC, Ghazalli Z, Ahmad F, Sulong AB. 2017. A Review of biocompatible metal injection moulding process parameters for biomedical applications. Mat Sci Eng. Elsevier. 78:1263-1276.

Hermawan H, Ramdan D, Djuansjah RP. 2011. Metals for biomedical applications. biomedical engineering - from theory to applications. London (UK): IntechOpen Publishers.

Jujur N, Sah J, Bakri A, Wargadipura AHS. 2015. Analysis of oxide inclusions on medical grade 316L stainless steel using local raw. J Int Tech. 7:1184-1190.

[Kemenkes RI] Kementrian Kesehatan Republik Indonesia. 2013. Riset kesehatan dasar. Badan Penelitian dan Pengembangan Kesehatan Kementrian Kesehatan RI. [accessed December 17th 2017]. www.depkes.go.id/ resources/download/general/Hasil\%20Riskesdas\%2020 13.pdf.

Kennedy RC, Marmor M, Marcucio R, Hunt CA. 2018. Simulation enabled search for explanatory mechanisms of the fracture healing process. PLoS Comput Biol. 14:e1005980.

Keohane EM, Smith LJ, Walenga JM. 2015. Rodaks's hematology: Clinical principles and applications. 5th ed. St. Louis (Missouri): Elsevier/Saunders. ISBN 978-0323-23906-6. 
Krecisz B, Kiec-Swierczynska M, Bakowic-Mitura K. 2006. Allergy to metals as a cause of orthopedic implant failure. Int J Med Env Health. 19:178-180.

Larsson TF, Martinez JMM, Valles JL. 2007. Biomaterials for healthcare. A decade of EU-Funded research. Belgium: Directorate General for Research, Industrial Technologies Unit.

Laing PG. 1979. Clinical experience with prosthetic materials' historical perspectives, current problems, and future directions, corrosions and degradations of implant materials. ASTM STP 684. Syrett BC, Acharya A, editors. Pennsylvania (USA): American Society for Testing and Materials. p. 199-211.

Lely SRM, Siswanto B, Aziz I, Anggraini AH. 2012. Effect of nitrogen ion dose on the corrosion resistance, the microstructure an the phase structure of the biomaterial austenitic stainless steel 316L. Yogyakarta (Indones): Pusat Sains dan Teknologi Akselerator, BATAN.

Manivasagam G, Dhinasekaran D, Rajaminickam A. 2010. Biomedical implants: corrosion and its prevention - a review. Rec Patents Corrosion Sci. 2:40-54.

McClung MR, Harvey NC, Fitzpatrick LA, Miller PD, Hattersley G, Wang Y, Cosman F. 2018. Effects of abaloparatide on bone mineral density and risk of fracture in postmenopausal women aged 80 years or older with osteoporosis. Menopause. 25:767-771.
Nielsen E, Bonsu N, Andras LM, Goldstein RY. 2018. The effect of canal fill on paediatric femur fractures treated with titanium elastic nails. J Child Ortho. 12:15-19.

Perren SM, Regazzoni P, Fernandez AA. 2017. How to choose between the implant materials steel and titanium in orthopedic trauma surgery: Part 2-biological aspects. Acta Chir Orthopaedic Traumatologie Cechoslovaca. 84:85-90.

[PTM-BPPT] Pusat Teknologi Material Badan Pengkajian dan Penerapan Teknologi. 2017. Kegiatan dan Kerjasama Pusat Teknologi Material BPPT. South Tangerang (Indones): Pusat Teknologi Material BPPT.

Saputri DNE, Dyah N, Abdulgani N. 2012. Jumlah total dan diferensial leukosit mencit (Musculus) pada evaluasi in vivo antikanker ekstrak spons laut Aaptos suberitoides. Surabaya (Indones): Bagian Program Studi Biologi Fakultas Matematika dan Ilmu Pengetahuan Alam Institut Teknologi Sepuluh Nopember.

Sinno H, Prakash S. 2013. Complements and the wound healing cascade: An updated review. Plast Surg Int. 2013:146764

Steel RGD, Torrie JH. 1995. Principles and procedures of statistic. A biometrical approach. 2nd ed. New York (USA): McGraw Hill Book Co. 